\title{
Radiation-induced two oil rich mutants in sesame (Sesamum indicum L.)
}

\author{
Sandipan Chowdhury ${ }^{1}$, Animesh K. Datta ${ }^{*}{ }^{1}$, Aditi Saha ${ }^{2}$ and Susmita Maity ${ }^{1}$ \\ ${ }^{1}$ Dept. of Botany, Genetics \& Plant Breeding Section, Univ. of Kalyani, Kalyani - 741235, India \\ ${ }^{2}$ Dept. of Botany, Narasinha Dutt College, Howrah - 711101, West Bengal \\ dattaanimesh@gmail.com
}

\begin{abstract}
Radiation (X-ray and gamma rays ) induced two productive oil rich 'plant type' mutants of sesame (Sesamum indicum L., var - B-67, family: Pedaliaceae) namely lax branching (angle of divergence $30.50^{\circ}$ to $32.35^{\circ}$ of primary branches in relation to main axis; control: $19.60^{\circ}-22.75^{\circ}$ ) and small flower (length: mutant $2.83 \mathrm{~cm} \pm 0.14$, control $-4.0 \mathrm{~cm} \pm 0.01$, breadth: mutant $1.53 \pm 0.03$, control $-1.83 \mathrm{~cm} \pm 0.03$ ) were cytogenetically (meiosis more or less alike to control, $2 n=26$; mutant traits were monogenic recessive to normal) and qualitatively assessed (seed yield and fatty oil contents were significantly higher in the mutants than parental cultivar but protein contents were lower; yield related traits namely total branches per plant, capsule on main axis and capsule length and plant height enhanced in small flower and lax branching mutants respectively than control) at $\mathrm{M}_{4}$ (rain fed kharif season). Lax branching and control plant types were given in multilocational trial (four districts - North 24 Parganas, Burdwan, Birbhum and Nadia of West Bengal) to assess seed yield and seed oil and protein contents, and the results obtained were discussed.
\end{abstract}

Keywords : Sesame, macromutants, oil rich, seed yield, protein content, multilocational trial.

\section{Introduction}

As a part of research initiated on radiation induced mutagenesis in sesame (Sesamum indicum L.; family: Pedaliaceae- an oil yielding plant of commerce and with immense therapeutic uses) for creating genetic variation and to screen desirable 'plant type' mutation for direct selection and /or efficient breeding , twenty macromutants were identified at $M_{2}$ (Chowdhury \& Datta, 2008) and this communication describes two oil rich (seed fatty oil content) mutants (Lax branching: gamma rays: 50 Gy4.68\%, 100 Gy- 0.74\%, 300 Gy- 0.32\%; X-rays: 100 Gy$0.17 \%, 0.32 \%$ and small flower. 200 Gy- $0.20 \%$ ). The mutants were also with higher seed yield than the parental cultivar.

\section{Materials and methods}

Lax branching and small flower mutants are spotted at $M_{2}$ and were cytogenetically assessed and evaluated for their quantitative traits at $M_{4}$ in relation to parental cultivar ( $S$. indicum var. B-67). Morphology, meiosis (as per Chowdhury et al. 2009), crossed (control as stigma parent $\mathrm{X}$ lax branching mutants as pollen parent, $\mathrm{F}_{1}$ plants raised and selfed to grow $F_{2}$ plants; $F_{2}$ segregation analyzed following $x^{2}$-test) and $M_{3}$ (selfed $M_{2}$ seeds of lax branching and small flower mutants segregated at $\mathrm{M}_{3}$ and $X^{2}$-test applied to study the segregation patterns) progenies and $M_{4}$ traits (true breeding $M_{4}$ plant types grown in RBD with 3 replication at kharif season and a maximum of 15 plants were analyzed for 10 parameters listed in Table 1 for each category; plot size: $3.0 \mathrm{~m} \times 1.5$ $\mathrm{m}$, spacing $30 \mathrm{~cm}$ between rows and $10 \mathrm{~cm}$ between plants) were studied. Seed protein and fatty oil contents extracted and estimated as described by Chowdhury (2009). Test of significance (t-test analysis) was computed to ascertain variations between plant types for different traits.

Lax branching mutant in relation to parental cultivar was evaluated (at kharif season) for seed yield and seed protein and fatty oil contents in four locations (districts) of West Bengal (Nadia: 9.91 p.c.- sand, 2.89 p.c-silt, 87.20 p.c-clay, nitrogen $-0.76 \%$, carbon- $3.25 \%$ and hydrogen$0.56 \%$; North 24 Parganas: 8.29 p.c- sand, 2.71 p.c- silt, 89.01 p.c-clay, $0.40 \%$-nitrogen, $0.83 \%$-carbon and $0.25 \%$ hydrogen; Burdwan: 37.91 p.c-sand, 0.80 p.c-silt, 61.29 p.c-clay, $0.86 \%$-Nitrogen, $1.78 \%$-carbon and $0.63 \%$ hydrogen; Birbhum: 57.14 p.c-sand, 1.11 p.c- silt, 41.75 p.c-clay, $0.86 \%$-nitrogen, $0.16 \%$-carbon and $0.18 \%$ hydrogen; carbon, hydrogen and nitrogen contents were analyzed by $\mathrm{CHN}$ analyzer). Major chemical contents in soil samples estimated by Atomic Absorption Spectroscopy are as follows: $\mathrm{Na}_{2} \mathrm{O}-0.901,0.972,0.436$ and $0.391 ; \mathrm{K}_{2} \mathrm{O}-2.397,2.451,1.611$ and 1.028; $\mathrm{Al}_{2} \mathrm{O}_{3}-$ 10.438,10.217, 9.160 and 2.589; $\mathrm{Fe}_{2} \mathrm{O}_{3}-5.656,4.252$, 4.787 and 3.958; $\mathrm{CaO}-1.175,0.806,0.955$ and 0.254 ; $\mathrm{MgO}-1.419,1.208,0.663$ and 0.202 per cent in Nadia, North 24 Parganas, Burdwan and Birbhum respectively. Amounts $(\mathrm{ppm})$ of trace elements $(\mathrm{Cu}, \mathrm{Zn}, \mathrm{Ni}, \mathrm{Co}, \mathrm{Mn}$, $\mathrm{Cd}, \mathrm{Cr}, \mathrm{V}$ and $\mathrm{Mo}$ ) were predominant in Nadia soil. Analysis of soil samples was done in Central Chemical Laboratory, Marine Wing of Geological Survey of India, Kolkata. Mean values (estimated over the districts) for 3 parameters were compared between control and mutant following the use of Duncun's t test analysis (alphabets denotes the degree of significance $a>b>c>d>e>f>g$ ).

\section{Results and discussion}

Lax branching (lax natured, angle of divergence of primary branches in relation to main axis at maturity was $30.50^{\circ}$ to $32.35^{\circ}$ as compared to $19.60^{\circ}-22.75^{\circ}$ in control) and small flower (length: mutant $-2.83 \mathrm{~cm} \pm 0.14$, control $-4.0 \mathrm{~cm} \pm 0.01, \mathrm{t}=2.94$ at $18 \mathrm{df}, \mathrm{p}<0.05$; breadth: mutant $1.53 \pm 0.03$, control $-1.83 \mathrm{~cm} \pm 0.03, \mathrm{t}=2.46,18$ $\mathrm{df}, \mathrm{p}<0.05)$ mutants showed monogenic recessive inheritance (lax branching : $F_{2}$ segregation - mutant 27,
Research article

CIndian Society for Education and Environment (iSee)
"Oil-rich mutant of sesame" http://www.indjst.org
Chowdhury et al. Indian J.Sci.Technol. 
Table 1. Quantitative traits in control and mutants at $M_{4}$

\begin{tabular}{|c|c|c|c|}
\hline \multirow[t]{2}{*}{ Attributes } & \multicolumn{3}{|c|}{ Plant types } \\
\hline & Control & $\begin{array}{c}\text { Lax } \\
\text { branching }\end{array}$ & Small flower \\
\hline Plant height & $113.4 \pm 1.3$ & $121.6^{*} \pm 3.4$ & $105.4^{*} \pm 3.9$ \\
\hline Primary branches/ plant & $5.9 \pm 0.3$ & $5.1 \pm 0.1$ & $5.1 \pm 0.6$ \\
\hline Total branches/ plant & $9.1 \pm 0.1$ & $9.1 \pm 0.2$ & $11.6^{*} \pm 0.3$ \\
\hline $\begin{array}{l}\text { Distance from base to first } \\
\text { branching }(\mathrm{cm})\end{array}$ & $25.5 \pm 2.7$ & $29.6 \pm 0.5$ & $22.2 \pm 0.1$ \\
\hline Capsule on main axis & $22.2 \pm 1.2$ & $22.5 \pm 0.7$ & $31.2^{* * *} \pm 0.8$ \\
\hline Total capsules per plant & $62.7 \pm 1.5$ & $57.3 \pm 2.1$ & $68.3 \pm 2.3$ \\
\hline Capsule length $(\mathrm{cm})$ & $2.2 \pm 0.02$ & $2.3 \pm 0.01$ & $3.0^{* *} \pm 0.2$ \\
\hline Seed yield (gm) & $6.6 \pm 0.03$ & $8.5^{* *} \pm 0.5$ & $7.2^{* *} \pm 0.2$ \\
\hline Seed protein content (\%) & $12.8 \pm 0.2$ & $10.7^{\star} \pm 0.8$ & $11.8 \pm 0.4$ \\
\hline Seed fatty oil content (\%) & $34.4 \pm 0.8$ & $41.5^{* * *} \pm 0.6$ & $38.6^{*} \pm 0.3$ \\
\hline & 00 & at $28 \mathrm{dt}$ & \\
\hline
\end{tabular}

normal- 88, total $115, x^{2}=0.143$ for 3 : 1 at $1 \mathrm{df}, p>0.70$; $M_{3}$ segregation - mutant 11 , normal 12 , total $23, x^{2}=0.043$ for $1: 1$ at $1 \mathrm{df}, \mathrm{p}>0.80$; small flower: $\mathrm{M}_{3}$ segregation mutant 02 , normal 07 , total $09, x^{2}=0.037$ for $3: 1$ at $1 \mathrm{df}, p>$ $0.90)$ small flower mutant had poor germination frequency $\left(\mathrm{M}_{4}-33.30 \%\right.$, control: $\left.86.70 \%\right)$.

Meiosis $(2 n=26)$ was more or less alike (control: $12.93 \mathrm{II}+0.14 \mathrm{I}$-mean/cell at MI, 71 cells scored; $100.0 \%$ cells at Al with 13/13 separation, 44 PMCs studied; lax branching mutant: 13II, mean/cell at $\mathrm{MI}, 21$ meiocytes scored; $100.0 \%$ cells at Al with $13 / 13$ separation, 35 cells observed; small flower

: $12.89 \mathrm{II}+0.22 \mathrm{I}$, mean/cell at MI, 27 cells scored; $100.0 \%$ cells at Al with $13 / 13$ separation, 25 PMCs studied ) in the plant types. Predominant chromosomal association recorded was 13II formation (control 92.96\%, lax branching - 100.0\%; small flower-88.89\%). Meiotic chromosomes in the plant types tended to form groups in 57.74, 52.38 and 59.26 per cent meiocytes of control (7 to 10 groups; maximum of 8 group class $28.17 \%$ ), lax branching (only 8 group class) and small flower ( 7 to 9,8 group class frequent -40.74 ) plant types respectively.

Analysis of agronomical parameters indicated (Table 1) that lax branching and small flower were promising mutants as they possessed higher seed yield and enhanced fatty oil content than the parental cultivar but protein content was lower in the mutants. Control and lax
Vol.2 No. 7 (July 2009)

ISSN: 0974- 6846

branching mutant under multilocational trial (pooled mean assessed) demonstrated similar responses (Table 2), thereby suggesting stability of the traits under the influence of different soil conditions. Seed yield and fatty oil traits responded best in Nadia soil; while, seed protein content in Burdwan. Yield related traits (Table 1) namely total branches per plant, capsule on main axis and capsule length, and plant height increased in small flower and lax branching mutants respectively than control thereby offering scope of direct selection of the mutants (lax branching - though detrimental for increasing plant population per unit area but high yield is compensating) as well as their utilization in efficient breeding and crop improvement not withstanding the exploitation of marker traits.

\section{Acknowledgement}

This research is grant aided by UGC.

\section{Reference}

1. Chowdhury S (2009) Radiation Induced Mutagenesis In Sesame (Sesamum indicum L.). Ph.D thesis. University of Kalyani, pp, 31.

2. Chowdhury $S$ and Datta AK (2008) Radiation induced macromutation in sesame (Sesamum indicum L.). J. Phytol. Res. 21, 181-185.

3. Chowdhury S, Datta AK and Maity S (2009) Cytogenetical and agronomical aspects of radiation induced marker trait mutants in sesame (Sesamum indicum L.). Indian J. Sci. Technol. 2 (5,6), 58-61. Domain site:http://www.indjst.org.

Table 2. Analysis of agronomic characters in sesame

\begin{tabular}{|c|c|c|c|c|c|c|c|c|c|c|c|c|c|c|c|}
\hline Plant & \multicolumn{5}{|c|}{ Seed yield (gm) } & \multicolumn{5}{|c|}{ Seed protein content (\%) } & \multicolumn{5}{|c|}{ Seed fatty oil content } \\
\hline & 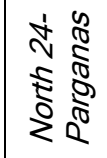 & సิ & 占 & $\begin{array}{l}0 \\
8 \\
8 \\
2\end{array}$ & 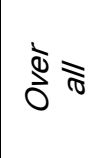 & 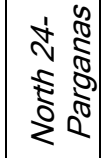 & ڤ్ & ș & $\frac{\pi}{8}$ & రి & 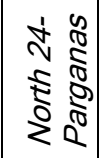 & ڤ్ & 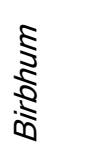 & $\begin{array}{l}: 0 \\
8 \\
0 \\
2\end{array}$ & ఏి \\
\hline Control & $\begin{array}{l}6.29 \pm \\
0.23 \\
\end{array}$ & $\begin{array}{l}6.37 \pm \\
0.18 \\
\end{array}$ & $\begin{array}{l}5.90 \pm \\
0.20 \\
\end{array}$ & $\begin{array}{l}6.37 \pm \\
0.16 \\
\end{array}$ & $\begin{array}{l}6.26 d \\
\pm 0.19 \\
\end{array}$ & $\begin{array}{l}12.00 \\
\pm 0.23 \\
\end{array}$ & $\begin{array}{l}13.90 \\
\pm 0.17 \\
\end{array}$ & $\begin{array}{l}13.13 \\
\pm 0.34 \\
\end{array}$ & $\begin{array}{l}12.83 \\
\pm 0.19 \\
\end{array}$ & $\begin{array}{l}12.97 f \\
\pm 0.23 \\
\end{array}$ & $\begin{array}{l}29.93 \\
\pm 0.18 \\
\end{array}$ & $\begin{array}{l}31.43 \\
\pm 0.69 \\
\end{array}$ & $\begin{array}{l}26.13 \\
\pm 1.30 \\
\end{array}$ & $\begin{array}{l}34.35 \\
\pm 0.81 \\
\end{array}$ & $\begin{array}{l}30.40 \mathrm{~cd} \\
\pm 0.74\end{array}$ \\
\hline $\begin{array}{l}\text { Lax } \\
\text { branching }\end{array}$ & $\begin{array}{l}7.69 \pm \\
0.92\end{array}$ & \begin{tabular}{|l|}
$7.79 \pm$ \\
1.02 \\
\end{tabular} & $\begin{array}{l}8.07 \pm \\
1.03\end{array}$ & $\begin{array}{l}9.21 \pm \\
0.03\end{array}$ & $\begin{array}{l}8.19 b \\
\pm 0.75 \\
\end{array}$ & $\begin{array}{l}10.27 \\
\pm 0.26 \\
\end{array}$ & $\begin{array}{l}11.47 \\
\pm 0.18 \\
\end{array}$ & $\begin{array}{l}11.00 \\
\pm 0.12 \\
\end{array}$ & $\begin{array}{l}10.70 \\
\pm 0.78 \\
\end{array}$ & $\begin{array}{l}10.86 g \\
\pm 0.33\end{array}$ & $\begin{array}{l}38.07 \\
\pm 0.24 \\
\end{array}$ & $\begin{array}{l}39.53 \\
\pm 0.41 \\
\end{array}$ & $\begin{array}{l}36.80 \\
\pm 0.35 \\
\end{array}$ & $\begin{array}{l}41.50 \\
\pm 0.61 \\
\end{array}$ & \begin{tabular}{|l|}
$38.90 a$ \\
\pm 0.40
\end{tabular} \\
\hline
\end{tabular}

Research article

CIndian Society for Education and Environment (iSee)
"Oil-rich mutant of sesame" http://www.indjst.org
Chowdhury et al. Indian J.Sci.Technol. 